\title{
PENYULUHAN MELALUI MEDIA TOKOH ADAT BAYAN (WETUTELU) TERHADAP PENGETAHUAN IBU BALITA TENTANG PESAN GIZI SEIMBANG
}

\author{
Denda Suwidari $^{1 *}$, Lalu Khairul Abdi ${ }^{1}$, Yuli Laraeni ${ }^{1}$ dan Abdul Salam ${ }^{1}$ \\ ${ }^{1}$ Jurusan Gizi, Poltekkes Kemenkes Mataram, Indonesia \\ Jalan Praburangkasari Dasan Cermen, Sandubaya Kota Mataram \\ Email : dsuwidari@gmail.com
}

\begin{tabular}{l}
\hline \hline Article Info \\
\hline Article history: \\
Received January $2^{\text {th }}, 2020$ \\
Revised February $5^{\text {th }}, 2020$ \\
Accepted March $30^{\text {th }}, 2020$
\end{tabular}

Keyword:

Balanced Nutrition

Massages; Cultural Figure;

Education.

\section{Kata Kunci :}

Penyuluhan; Pen Pesan Gizi seimbang; Tokoh adat.

\begin{abstract}
Background : Factors of education and knowledge mothers of toddlers can influence nutritional status. One effort to improve nutritional status is to increase knowledge about nutrition with nutrition counseling. Knowledge can be influenced by education, people who are highly educated will have broader knowledge and have openness to accept new things. While people with low education tend to have old thinking patterns and are less open to new things including a strong area of customs and traditional. One of the ways to influence the mindset of community with these condition is to use a communication facilitator who is believed to be a role model for the community. So, in this reseach the role of cultural figure was used, so that people receive more material.
\end{abstract}

Objectives : Knowing the influence of educatuin by cultural figure on knowledge of mothers of toddlers about balance nutritional massages.

Methods : This Research is pre-experimental study. Which allows testing of changes that occur after the intervention. This research design was used one grup pretest-posttest design.

Results : there is an increase in knowledge in the form of difference in scores from pretest to posttest. Based on the result of the analysis using wilcoxon, the influence of education by cultural figure on the knowledge of mothers of toddlers about balance nutritional massages obtained $p=0.00$ atau $p<0.05$ meaning there is influence.

Conclusion : There is the influence of education by cultural figure on knowledge of mothers of toddlers about balanced nutrition massages.

\footnotetext{
ABSTRAK

Latar Belakang : Salah satu upaya mengatasi masalah gizi adalah dengan meningkatkan pengetahuan tentang gizi melalui penyuluhan gizi. Pengetahuan dapat dipengaruhi oleh pendidikan, orang yang berpendidikan tinggi cenderung memiliki pengetahuan yang lebih luas dan memiliki keterbukaan untuk menerima hal baru. Sedangkan seseorang yang berpendidikan rendah cenderung memiliki pola pemikiran lama dan kurang terbuka terhadap hal baru termasuk pada daerah yang sangat kuat memegang adat istiadatnya. Salah satu cara untuk mempengaruhi pola pikir masyarakat pada kondisi demikian adalah dengan menggunakan fasilitator komunikasi yang dipercaya dan dapat menjadi panutan bagi masyarakat tersebut. Sehingga dalam penelitian ini peran tokoh adat digunakan agar masyarakat lebih menerima materi yang disampaikan.
} 
Tujuan : Untuk mengetahui pengaruh penyuluhan melalui media tokoh adat Wetu Telu Bayan terhadap pengetahuan ibu balita tentang pesan gizi seimbang.

Metode : Penelitian ini merupakan penelitian pre-eksperimental yang memungkinkan menguji perubahan yang terjadi setelah dilakukannya intervensi, rancangan penelitian yang digunakan adalah one-group pre test- post test design.

Hasil : Terjadinya peningkatan skor pengetahuan berupa selisih skor dari pretest ke posttest. Analisis menggunakan Wilcoxon mengenai pengaruh penyuluhan pesan gizi seimbang oleh tokoh adat terhadap pengetahuan ibu balita diperoleh hasil $p=0.00$ atau $p<0.05$ artinya ada pengaruh.

Kesimpulan : Ada pengaruh penyuluhan melalui media tokoh adat wetu telu Bayan terhadap pengetahuan ibu balita tentang pesan gizi seimbang.

Copyright () Jurnal Gizi Prima All rights reserved.

\section{PENDAHULUAN}

Keberhasilan pembangunan suatu bangsa ditentukan oleh ketersediaan sumber daya manusia (SDM) yang berkualitas lahir maupun batin, yang memiliki fisik yang tangguh, mental yang kuat, kesehatan yang prima, dan pikiran yang cerdas. Keadaan demikian sangat ditentukan oleh status gizi setiap masyarakatnya (DiKes NTB, 2015).

Berdasarkan data hasil pemantauan status gizi balita diprovinsi NTB indeks BB/U diketahui bahwa Kasus gizi buruk yang terjadi di Kabupaten Lombok Utara yaitu sebesar 3,8\% sedangkan kasus gizi kurang yaitu 21,8 \% yaitu angka tertinggi ketiga setelah Kabupaten Dompu dan Kota Bima. Bahkan angka kejadian gizi kurang di Kabupaten Lombok Utara lebih tinggi dibandingkan angka kejadian gizi kurang secara Keseluruhan di Provinsi NTB (PSG NTB, 2017).

Masalah gizi adalah masalah kesehatan masyarakat yang penanggulanganya tidak dapat dilakukan dengan pendekatan medis dan pelayanan kesehatan saja. Masalah gizi disamping merupakan sindrom kemiskinan yang erat kaitanya dengan masalah pangan ditingkat rumah tangga dan juga menyangkut aspek pengetahuan serta perilaku yang kurang mendukung pola hidup sehat (Supariasa, 2002).

Kurangnya pengetahuan tentang gizi berdampak kurangnya pengetahuan atau informasi tentang gizi untuk menerapkan informasi tersebut dikehidupan sehari-hari. Salah satu upaya menanggulangi masalah gizi adalah melalui peningkatan pengetahuan seseorang dengan melakukan penyuluhan gizi.

Partisipasi masyarakat dalam perbaikan masalah gizi dapat dilakukan melalui peningkatan pengetahuan bidang gizi, peran tokoh adat dalam pembangunan kesehatan sangat diperlukan melalui pengaruh yang diberikan. Tokoh adat cenderung mempunyai kedekatan ikatan emosional dengan masyarakat, maka untuk mengakomodir berbagai gagasan-gagasan untuk kepentingan masyarakat, tokoh adat diharapkan mampu meningkatkan partisipasi masyarakat. Keberadaan tokoh adat, cenderung masih terikat oleh nilai-nilai lama yakni tradisi dan ikatan kulturalnya. Kekuatan tokoh memang masih bertumpu pada ikatan primordial, khususnya ikatan keluarga, budaya dan kesukuan.

Menurut (Ahira, 2007) tokoh masyarakat merupakan: kekayaan pengetahuan maupun kesuksesannya dalam menjalani kehidupan. Ia menjadi contoh atau teladan bagi orang lain karena pola pikir yang dibangun melalui pengetahuan yang dimiliki sehingga dipandang sebagai seseorang yang pandai dan bijaksana juga menjadi panutan bagi banyak orang. Menurut (Koetnjaraningrat, 1983) salah satu yang termasuk kedalam kategori tokoh masyarakat ialah tokoh adat yang merupakan kategori tokoh masyarakat informal.

Masyarakat yang tingkat pendidikannya rendah pada umumnya lebih terbuka dengan orang sekitar atau orang yang dianggap memiliki peran penting dalam lingkungan masyarakat. Sehingga untuk memberikan 
penyuluhan tentang gizi tersebut peneliti bekerja sama dengan tokoh adat setempat agar masyarakat lebih mudah menerima apa yang disampaikan baik dari segi materi maupun bahasa yang lebih mudah dipahami. Selain itu tokoh adat setempat lebih mengerti keadaan masyarakat dan lebih memiliki peran untuk mengubah pola pikir dan perilaku masyarakat. Sehubungan dengan hal-hal diatas penting untuk melakukan penelitian tentang pengaruh penyuluhan terhadap pengetahuan tentang pesan gizi seimbang. Penelitian ini dilakukan untuk mengetahui tingkat pengetahuan masyarakat setelah diberikan penyuluhan oleh tokoh adat setempat tentang pesan gizi seimbang.

\section{METODE PENELITIAN}

Populasi pada penelitian ini adalah seluruh ibu balita yang berdomisili di Dusun Batu Jompang Desa Bayan Kecamatan Bayan Kabupaten Lombok Utara. Sampel pada penelitian ini diambil dengan menggunakan teknik total sampling yaitu teknik penetapan sampel dengan cara mengambil keseluruhan dari populasi yakni seluruh ibu balita yaitu sebanyak 24 orang. Desain penelitian adalah pre-eksperimental yang memungkinkan menguji perubahan yang terjadi setelah dilakukannya intervensi, rancangan penelitian yang digunakan adalah one-group pre test- post test design.

Pelaksaan penelitian dilakukan dengan beberapa tahap, tahap pertama adalah berkoordinasi dengan tokoh adat tentang kesediaan menjadi penyuluh serta berkoordinasi dengan petugas gizi puskesmas mengenai kesedian untuk melalukan pelatihan kepada tokoh adat tesebut. Tahap kedua adalah pemberian pretest dan melalukan pelatihan serta melakukan evaluasi terhadap pengetahuan tokoh adat tentang pesan gizi seimbang melalui pelaksanaan posttest. Tahap selanjutnya adalah melakukan pretest kepada responden, dan dilanjutkan dengan pemberian penyuluhan tentang pesan gizi seimbang selama dua kali, dan tahap akhir adalah melakukan posttest kepada responden.

Data yang diperoleh dari hasil wawancara menggunakan lembar identitas yaitu data karakteristik yang meliputi umur, pendidikan dan pekerjaan responden. Kemudian disajikan dalam bentuk tabel distribusi frekuensi. Data Pretest dan posttest juga disajikan dalam bentuk tabel kategori pengetahuan dan dianalisis dengan menggunakan analisis statistik Wilcoxon pada tingkat kepercayaan 95\% $(\alpha=0,05)$. Analisis statistik ini dilakukan dengan menggunakan software program SPSS. Apabila $p<\alpha 0,05$ maka ada pengaruh signifikan pada pengetahuan ibu balita.

\section{HASIL PENELITIAN}

\section{Karakteristik Responden}

Hasil penelitian berupa karakteristik dari 24 orang ibu balita di Dusun Batu Jompang Desa Bayan Kecamatan Bayan Kabupaten Lombok Utara. Karakteristik ibu balita tersebut diperoleh dari hasil wawancara menggunakan lembar identitas responden. Karakteristik ibu balita dapat dilihat pada tabel 1 berikut :

Tabel 1. Distribusi Frekuensi Karakteristik Responden di Dusun Batu Jompang Desa Bayan Kecamatan Bayan Kabupaten Lombok Utara Tahun 2019

\begin{tabular}{|c|c|c|}
\hline Karakteristik Ibu Balita & $\mathbf{n}$ & $\%$ \\
\hline \multicolumn{3}{|l|}{ Umur : } \\
\hline$<20$ tahun & 1 & 4.17 \\
\hline 20-30 tahun & 20 & 83.33 \\
\hline$>30$ tahun & 3 & 12.50 \\
\hline Jumlah & 24 & 100 \\
\hline \multicolumn{3}{|l|}{ Pendidikan : } \\
\hline Tidak sekolah & 18 & 75.00 \\
\hline SD & 2 & 8.33 \\
\hline SMP & 4 & 16.67 \\
\hline Jumlah & 24 & 100 \\
\hline \multicolumn{3}{|l|}{ Pekerjaan : } \\
\hline Petani & 22 & 91.67 \\
\hline Ibu Rumah Tangga & 2 & 8.33 \\
\hline Jumlah & 24 & 100 \\
\hline
\end{tabular}

Sumber : Data primer 2019 
Berdasarkan tabel di atas dapat dilihat bahwa sebagian besar umur ibu balita sebagian besar pada rentang 2030 tahun yaitu sebanyak 20 orang $(83.33 \%)$. Karakteristik ibu dilihat dari pendidikan yaitu sebanyak 18 orang $(75.00 \%)$ ibu balita tidak sekolah. Pekerjaan ibu sebagian besar adalah petani berjumlah 22 orang (91.67).

\section{Kategori Pengetahuan}

Hasil penelitian berupa kategori pengetahuan ibu balita di Dusun Batu Jompang Desa Bayan Kecamatan Bayan Kabupaten Lombok Utara. Pengetahuan ibu balita diukur menggunakan kuisioner. Pengetahuan ibu balita dapat dilihat pada tabel 2 berikut :

Tabel 2. Distribusi Frekuensi Kategori Pengetahuan Ibu Balita Sebelum Intervensi dan Sesudah Intervensi

\begin{tabular}{lccc}
\hline \multicolumn{1}{c}{ Kategori Pengetahuan } & n & \% \\
\hline Pretest : & 0 & 0.0 \\
\hline Baik & 18 & 75.0 \\
\hline Cukup & 6 & 25.0 \\
\hline Kurang & Jumlah & $\mathbf{2 4}$ & $\mathbf{1 0 0}$ \\
\hline \multicolumn{1}{l}{ Posttest : } & & 22 & 91.67 \\
\hline Baik & & 2 & 8.33 \\
\hline Cukup & 0 & 0.0 \\
\hline Kurang & Jumlah & $\mathbf{2 4}$ & $\mathbf{1 0 0}$ \\
\hline
\end{tabular}

Berdasarkan hasil penelitian diperoleh hasil bahwa pada tahap pretest sebanyak 6 orang (25.00\%) ibu balita memiliki pengetahuan kurang, 18 orang $(75.00 \%)$ ibu balita memiliki pengetahuan cukup dan tidak ada ibu balita $(0.0 \%)$ yang memiliki pengetahuan baik sebelum diberikan intervensi berupa penyuluhan. Sedangkan pada tahap posttest diperoleh hasil bahwa 22 orang (91.67\%) ibu balita memiliki pengetahuan baik, 2 orang $(8.33 \%)$ memiliki pengetahuan cukup dan tidak ada ibu balita $(0.0 \%)$ yang memiliki pengetahuan kurang setelah diberikan intervensi berupa penyuluhan.

\section{PEMBAHASAN}

\section{Karakteristik Responden}

\section{Karakteristik Berdasarkan Umur Ibu Balita}

Sebagian besar umur ibu balita di Dusun Batu Jompang adalah 19-45 tahun yang termasuk usia sangat produktif yaitu kisaran antara 15-49 tahun. Menurut (Notoatmodjo, 2007), menyatakan bahwa salah satu faktor yang berhubungan dengan pengetahuan adalah umur. Semakin tua umur seseorang, pengetahuan yang dimiliki akan semakin banyak. Namun dimasa sekarang tidak jarang usia muda memiliki pengetahuan yang banyak dibandingkan dengan usia yang lebih tua. Hal tersebut banyak dibandingkan dengan faktor lain yang juga dapat mempengaruhi pengetahuan selain faktor umur, seperti media masa dan juga informasi.

\section{Karakteristik Berdasarkan Pendidikan Ibu Balita}

Dari hasil penelitian yang diperoleh bahwa dari masing-masing responden yang memiliki tingkat pendidikan yang berbeda. Sehingga berpengaruh terhadap pengetahuan tentang pesan gizi seimbang, nilai terendah dari skor pengetahuan pretest maupun posttest diperoleh oleh ibu balita yang tidak sekolah sedangkan nilai tertinggi yang diperoleh baik pretest maupun posttest adalah dari ibu balita yang pendidikanya SMP, ternyata terbukti bahwa pendidikan formal seseorang mempengaruhi pengetahuan. Hal tersebut sejalan dengan (Citraningtyas, 2012) semakin tinggi pendidikan seseorang, maka semakin tinggi pengetahuan gizi dan kesehatannya. Pengetahuan erat kaitanya dengan pendidikan dimana diharapkan seseorang dengan pendidikan tinggi, maka orang tersebut akan semakin luas pula pengetahuannya (Notoatmodjo, 2007)

\section{Karakteristik Berdasarkan Pekerjaan Ibu Balita}

Pekerjaan juga dapat mempengaruhi pengetahuan tentang pesan gizi seimbang, dimana pekerjaan akan mempengaruhi interaksi dan sumber informasi. Dari hasil penelitian menunjukkan bahwa skor pengetahuan 
ibu balita paling tinggi diperoleh oleh ibu balita yang bekerja sebagai kader posyandu, sehingga pekerjaan ibu balita tersebut mempengaruhi pengetahuan tentang pesan gizi seimbang, selain itu juga orang yang terlibat menjadi kader posyandu akan dapat memperoleh banyak informasi tentang gizi dan kesehatan melalui pelatihan atau penyuluhan yang sering diikuti. Menurut (Rahayu, 2010) lingkungan pekerjaan dapat menjadikan seseorang mendapatkan pengalaman dan pengetahuan, baik secara langsung maupun tidak langsung. Sejalan dengan (Notoatmodjo, 2010) pekerjaan seseorang sangat berpengaruh terhadap proses mengakses informasi yang dibutuhkan terhadap suatu obyek.

\section{Pengetahuan Sebelum dan Setelah Penyuluhan \\ Pengetahuan Sebelum Penyuluhan (Pretest)}

Pengetahuan sebelum perlakuan pada saat diberikannya pretest yaitu bertujuan untuk mengetahui apakah ada diantara responden yang sudah mengetahui mengenai materi yang akan disampaikan. Pretest juga bisa diartikan sebagai kegiatan menguji pengetahuan responden terhadap materi yang akan disampaikan sebelum kegiatan dilakukan. Pengukuran pengetahuan dapat dilakukan dengan cara wawancara atau angket yang menanyakan tentang isi materi yang akan diukur (Notoatmodjo, 2007).

Dari hasil pretest kurangnya pengetahuan ibu balita pada aspek dampak jika mengkonsumsi sayur dipengaruhi oleh ketidaktahuan ibu tentang manfaat sayur bagi kesehatan tubuh. Ketidak mampuan ibu balita menjawab aspek tersebut dapat dipengaruhi oleh pendidikan yang rendah. Menurut (Notoatmodjo, 2010) pengetahuan umumnya dapat diperoleh dari informasi yang disampaikan oleh orang tua, guru, dan media massa. Orang yang pendidikan rendah cenderung lebih sedikit menerima informasi, sehingga hal tersebut akan mempengaruhi pengetahuan. Selain pendidikan, pengetahuan juga dapat diperoleh melalui media cetak maupun media eletronik, akan tetapi antara pendidikan dan sumber informasi sangat erat kaitanya. Dimana penyerapan informasi sangat dipengaruhi pendidikan, misalnya masyarakat yang pendidikan rendah dan tidak bisa baca tulis akan kesulitan untuk menyerap informasi baik yang bersumber dari media cetak maupun media elektronik.

Sedangkan aspek tertinggi pengetahuan ibu pada tahap pretest adalah mengenai buah apa yang mengenyangkan bila diberikan sebagai selingan, dimana menurut ibu balita buah pisang adalah salah satu contoh buah yang dapat mengenyangkan jika diberikan sebagai selingan karena menurut ibu buah pisang memiliki tekstur yang padat sehingga mampu memberikan rasa kenyang. Kemampuan ibu balita untuk menjawab pretest tersebut dapat dipengaruhi oleh pengalaman, seperti yang dikemukakan oleh (Rahayu, 2010) pengalaman merupakan sebuah kejadian atau peristiwa yang pernah dialami oleh seseorang dalam berinteraksi dengan lingkunganya. Sehingga dari pengalaman mengkonsumsi buah-buahan lokal atau buah yang sering dijumpai, konsumsi buah pisang adalah paling dapat mengenyangkan menurut ibu balita.

Rata-rata pengetahuan responden pada tahap pretest adalah cukup, hal tersebut dapat dipengaruhi oleh kelemahan pada kuisioner yang mungkin terlalu mudah dan tidak dilakukan uji validitas terhadap kuisioner terlebih dahulu. Selain itu yang dapat mempengaruhi pengetahuan responden yang sudah terpapar materi tentang pesan gizi seimbang yang akan disampaikan atau bisa juga pengetahuan diperoleh dari pengalaman. Menurut (Notoatmodjo, 2007) ada beberapa faktor yang mempengaruhi pengetahuan seseorang yaitu pendidikan, media masa/ informasi, sosial budaya dan ekonomi, lingkungan, pengalaman dan usia.

\section{Pengetahuan Setelah Penyuluhan (Posttest)}

Posttest yang diberikan adalah bentuk dari evaluasi akhir saat materi yang dilakukan sudah selesai dan pada saat itu diberikan posttest yang bertujuan untuk mengetahui apakah ibu balita sudah mengerti tentang materi yang sudah disampaikan.

Dari hasil posttest aspek pengetahuan ibu balita paling rendah adalah pada jumlah air yang sebaiknya dikonsumsi dalam sehari, dimana rata-rata ibu balita tidak mengetahui volume air yang sebaiknya dikonsumsi sehari selain itu ibu balita juga tidak pernah menghitung volume atau banyaknya air yang dikonsumsi sehari-hari karena kecenderungan konsumsi air disesuaikan dengan kondisi tubuh tanpa menghitung kekurangan ataupun kelebihan konsumsi air dari yang dianjurkan.

Sedangkan aspek tertinggi pengetahuan ibu balita pada tahap posttest adalah pada sejak usia berapa anak sebaiknya diberikan makan selain Asi, seluruh ibu balita menjawab sejak balita berusia 6 bulan, dimana sebenarnya sebelum diberikan intervensi ibu balita sudah mengetahui usia pemberian makan yang baik bagi 
anak, sehingga intervensi berupa penyuluhan tersebut dapat juga diartikan sebagai review materi sehingga ibu balita terus mengingat hal tersebut dan kedepannya akan dapat diterapkan dikehidupan sehari-hari. Hal tersebut berbanding lurus dengan pendapat (Mubarak, 2007)

bahwa salah satu tingkat pengetahuan dan yang paling mendasar adalah tahu yaitu diartikan sebagai mengingat suatu materi yang sudah dipelajari atau diketahui sebelumnya, mengingat kembali (recall) terhadap sesuatu yang spesifik dari seluruh bahan atau rangsangan yang diterima.

Rata-rata pengetahuan responden pada tahap posttest adalah dalam kategori baik, hampir sama dengan pada tahap pretest hal tersebut dapat dipengaruhi oleh kelemahan pada kuisioner karena terlalu mudah dan tidak dilakukan uji validitas terhadap kuisioner terlebih dahulu. Selain itu yang dapat dipengaruhi oleh pengalaman sehingga responden akan terus mengingat hal tersebut karena sudah pernah dilakukan.

Peningkatan pengetahuan responden terjadi karena adanya perlakuan berupa pemberian penyuluhan dan diskusi. Selain itu juga peningkatan pengetahuan responden dipengaruhi oleh penggunaan bahasa daerah selama proses penyuluhan sehingga responden lebih mengerti dan paham materi yang disampaikan.

\section{Pengaruh penyuluhan oleh tokoh adat}

Berdasarkan hasil analisis pretest dan posttest terhadap penelitian yang telah dilakukan maka dapat disimpulkkan bahwa ada pengaruh pemberian penyuluhan pesan gizi seimbang oleh tokoh adat terhadap pengetahuan ibu balita. Peningkatan pengetahuan tersebut dapat berupa peningkatan skor pengetahuan maupun peningkatan kategori pengetahuan. Hal tersebut tidak terlepas dari peranan tokoh adat yang mampu menjadi penyuluh atau fasilitator komunikasi yang dapat mempengaruhi partisipasi dan pengetahuan ibu balita.

Menurut (Eka Yuliana, 2013) dalam jurnal peranan kepala adat dalam sosialisasi program keluarga berencana di Pampang Kelurahan Sungai Siring Samarinda mengemukakan bahwa peran kepala adat atau tokoh adat/ tokoh adat sebagai fasilitator komunikasi telah terlaksana, yaitu kepala adat sebagai pemuka pendapat mendapatkan informasi dari petugas penyuluh PLKB dan kemudian kepala adat meneruskan kepada masyarakat. Dibutuhkan perantara yang tepat agar pesan tersebut dapat diterima dengan baik oleh masyarakat. Perantara tersebut yaitu kepala adat sebagai fasilitator komunikasi. Dengan pemilihan fasilitator komunikasi yang tepat, diharapkan dapat menghasilkan pemahaman yang baik pula tentang materi yang disampaikan. Hal tersebut berbanding lurus dengan penelitian yang sudah dilakukan dimana diharapkan peran tokoh adat sebagai fasilitator komunikasi dapat terlaksana dengan baik dan mempengaruhi pengetahuan masyarakat.

Strategi KIE/ komunikasi, informasi dan edukasi diterapkan dalam penyampaian pesan gizi seimbang kepada masyarakat berdasarkan sasaran dan tujuan yang dituju untuk masing-masing sasaran adalah pemberdayaan masyarakat agar berperan serta secara aktif dalam kegiatan penyuluhan gizi melalui diseminasi informasi, orientasi atau pelatihan dan menjalin kerjasama terhadap tokoh-tokoh lokal seperti tokoh agama, tokoh adat, PKK, guru, penyuluh pertanian, wartawan, kader dll untuk meningkatkan kemampuan serta keterampilanya dalam penyuluhan pesan gizi seimbang (Pedoman Gizi Seimbang, 2014)

Mengubah pola pikir masyarakat pedesaan tentang kesehatan memang tidak mudah, karena sifat masyarakat desa yang homogen juga terlihat pada sistem kepercayaannya. Kepercayaan masyarakat terutama mengenai kesehatan medis dan peran tenaga kesehatan masih kurang, seperti yang dikemukakan oleh (Lukman, 2013) dalam jurnalnya yang berjudul "faktor sosial budaya dan orientasi masyarakat dalam berobat" menyebutkan bahwa pengaruh budaya yang ada pada masyarakat merupakan salah satu alasan utama masyarakat pedesaan memilih alternatif lain mengapa orang lebih cenderung pergi kepada para normal dari pada ke Dokter atau Tenaga kesehatan lain dalam masalah kesehatan.

Faktanya pola pemikiran yang masih awam tentang gizi dan kesehatan masih berkembang dimasyarakat pelosok seperti di Dusun Batu Jompang. Menurut salah satu ibu balita bahwa kebiasaan atau tradisi masyarakat khususnya dibidang kesehatan akan terus berkembang dan hampir tidak bisa ditinggalkan, ketika posyandu selalu diberikan informasi tentang kesehatan, akan tetapi ibu balita hanya akan sekedar tahu dan tidak menerapkanya dikehidupan sehari-hari jika itu merupakan hal baru dan tidak sesuai dengan tradisi mereka selama ini (Anonim, 2019). Seperti salah satu contoh pesan gizi seimbang yaitu usia pemberian makan bayi rata-rata masyarakat sudah mengetahui usia pemberian makan yang baik pada bayi itu adalah 
setelah bayi berumur 6 bulan, akan tetapi masyarakat masih awam tentang penggunaan istilah Asi Ekslusif. Dalam pelaksanaanya rata-rata masyarakat tidak menerapkan Asi Ekslusif dengan alasan ketika bayi berumur kurang dari 6 bulan meskipun sudah diberikan makanan selain Asi akan tetapi baik-baik saja bahkan bayi menjadi gemuk dan sehat.

Kedepannya cara yang sebaiknya dilakukan untuk mengubah pola pikir masyarakat agar dapat menciptakan masyarakat yang sehat adalah melakukan advokasi baik lintas program maupun lintas sektoral dengan tujuan utama yaitu untuk meningkatkan derajat kesehatan masyarakat, salah satu untuk mengubah pola pikir dan perilaku kesehatan masyarakat adalah dengan bekerja sama dengan tokoh adat setempat, seperti yang dikemukakan oleh Green yang dikutip (Notoatmodjo, 2003) tentang konsep perilaku yaitu dipengaruhi oleh faktor penguat yang termasuk sikap dan perilaku tokoh agama, tokoh adat juga petugas kesehatan yang bisa dijadikan panutan bagi masyarakat.

Kesimpulan yang dapat diambil dari penelitian tersebut adalah penyuluhan yang diberikan oleh tokoh adat berpengaruh terhadap peningkatan pengetahuan ibu balita, terlebih pada kelompok masyarakat pedesaan yang masih memegang teguh prinsip kekeluargaan dan kesukuan. Pada Umumnya masyarakat pedesaan juga lebih cenderung mempercayai orang yang dianggap memiliki peran dalam masyarakat, terlebih terhadap orang yang pernah memimpin kelompok masyarakat tersebut.Kelemahan penelitian ini adalah pada tahap koordinasi dengan tokoh adat, dimana tokoh adat yang digunakan sebagai penyuluh adalah tokoh adat dengan latar belakang ilmu sosial dan tidak ada sama sekali latar belakang ilmu kesehatan, akan tetapi kendala tersebut bisa diatasi dengan memberikan materi pesan gizi seimbang serta dengan memantau setiap hari pemahaman materi oleh tokoh adat tersebut.

Keberhasilan penelitian dapat dilihat berdasarkan kategori peningkatan pengetahuan ibu balita sebelum dan setelah diberikan intervensi berupa penyuluhan pesan gizi seimbang. Persentase keberhasilan penelitian diperoleh dengan cara membandingkan jumlah sampel yang memiliki pengetahuan kurang, cukup dan baik. Kemudian dari masing-masing kategori tersebut dikelompokkan dan dihitung persentase peningkatan pengetahuan ibu balita, sehingga diperoleh hasil bahwa persentase peningkatan pengetahuan ibu balita tertinggi adalah pada kategori pengetahuan baik. Sebelum diberikan intervensi 24 orang ibu balita tersebut memiliki pengetahuan kurang dan cukup, kemudian setelah diberikan intervensi 22 orang $(91,67 \%)$ ibu balita dalam kategori pengetahuan baik. Sehingga dari persentase peningkatan pengetahuan tersebut dapat disimpulkan bahwa penelitian penyuluhan pesan gizi seimbang oleh tokoh adat ini berhasil meningkatkan pengetahuan ibu balita tentang pesan gizi seimbang.

Selain dengan mengacu kepada kategori pengetahuan, akan lebih rinci jika keberhasilan penelitian diuraikan menurut selisih nilai pengetahuan ibu balita sebelum dan setelah diberikan intervensi. Selisih yang diperoleh dari hasil pretest dan posttest tersebut sangat bervariasi dan signifikan jika dilihat dari jumlah ibu balita yang pengetahuanya meningkat, karena seluruh ibu balita yang diberikan intervensi skor pengetahuannya meningkat. Oleh karena itu dapat dikatakan juga bahwa jika dilihat dari peningkatan skor pengetahuan ibu balita, maka penelitian penyuluhan pesan gizi seimbang oleh tokoh adat ini berhasil meningkatkan pengetahuan ibu balita tentang pesan gizi seimbang.

\section{KESIMPULAN}

Dari hasil penelitian tersebut dapat disimpulkan bahwa terjadi peningkatan pengetahuan ibu balita sebelum dan sesudah diberikan penyuluhan gizi seimbang oleh tokoh adat. Serta Peran tokoh adat yang mampu menyesuaikan pembahasan materi dan kebutuhan masyarakat ternyata mampu meningkatkan pengetahuan ibu balita tentang pesan gizi seimbang.

\section{SARAN}

Berdasarkan hasil penelitian, saran yang dapat diajukan yaitu Sebaiknya peran tokoh adat lebih dimanfaatkan terutama peran sebagai penyuluh kesehatan dan gizi kepada kelompok masyarakat yang masih memengang kuat nilai adat istiadat dalam kehidupan sehari-harinya dengan harapan agar kelompok masyarakat tersebut lebih mudah menerima materi yang disampaikan.

DAFTAR PUSTAKA

Ahira, A. (2007). Peran Tokoh Masyarakat bagi Pembagangunan Indonesia. 
Cut, R. azria, \& Husnah. (2015). Pengaruh penyuluhan gizi terhadap pengetahuan dan perilaku ibu tentang gizi seimbang balita kota banda aceh. Pengaruh Penyuluhan Gizi Terhadap Pengetahuandan Perilaku Ibu Tentang Gizi Seimbang Balita Kota Banda Aceh, 1(2016), 87-92.

Di, S., Duasudara, K., Ranowulu, K., \& Bitung, K. (1945). Peran Tokoh adat Dalam Meningkatkan Partisipasi Pembangunan, 1-17.

Dinkes NTB. 2015. Profil Kesehatan Provinsi Nusa Tenggara Barat. Mataram: Dinas Kesehatan Nusa Tenggara Barat.

Direktorat Gizi Masyarakat Direktorat Jendral Kesehatan Masyarakat. Buku Saku Pemantauan Status Gizi dan Indikator Kinerja Gizi Tahun 2017. Jakarta Kementerian Kesehatan RI ; 2017.

Eka. (2013). Peranan Kepala Adat dalam Sosialisasi Program Keluarga Berencana di Pampang Kelurahan Sungai Siring Samarinda.

Citraningtyas, G. (2012). Pengaruh Penyuluhan Penggunaan Antibiotika Terhadap Tingkat Pengetahuan Masyarakat di Kota Manado. Prodi Farmasi FMIPA UNSRAT.

Khotimah, K. (2015). Peran Tokoh Agama dalam Pengembangan Sosial Agama di Banyumas. IAIN Purwokerto.

Koetnjaraningrat. (1983). Metode-Metode Penelitian Masyarakat. Jakarta: Gramedia.

Lukman. (2013). Faktor Sosial Budaya dan Orientasi Masyarakat dalam Berobat.

Mubarak. (2007). Promosi Kesehatan Sebuah Pengamatan Proses Belajar Mengajar Dalam Pendidikan. Yogyakarta: Graha Ilmu.

Notoatmodjo. (2003). Pendidikan dan Perilaku Kesehatan. Jakarta: Rineka Cipta.

Notoatmodjo. (2007). Promosi Kesehatan dan Ilmu Perilaku. Jakarta: Rineka Cipta.

Rahayu. (2010). Hubungan Pendidikan Orang Tua Dengan Perubahan Status Stunting dari Usia 6-12 Bulan ke Usia 3-4 Tahun.

Supariasa, I. D. N. dkk. (2002). Penilaian Status Gizi. Jakarta: EGC. 